\title{
Pemoderasi Pengaruh Kompetensi Aparatur Desa Dan Sistem Pengendalian Internal Pada Pencegahan Fraud
}

\author{
Luh Ayu Marsita Dewi ${ }^{1}$ \\ I Gusti Ayu Eka Damayanthi ${ }^{2}$ \\ ${ }^{1,2}$ Fakultas Ekonomi dan Bisnis Universitas Udayana (Unud), Bali, Indonesia \\ e-mail: marsitadewi46@yahoo.com
}

\begin{abstract}
ABSTRAK
Tujuan penelitin ini adalah untuk menguji internal locus of control dalam memoderasi pengaruh kompetensi aparatur desa dan sistem pengendalian internal pada pencegahan fraud. Penelitian dilakukan di seluruh kantor desa Kota Denpasar. Jumlah sampel yang diambil sebanyak 81 orang aparatur desa, dengan metode sampel jenuh. Pengumpulan data dilakukan dengan kuisioner dan wawancara. Moderate Regression Analysis (MRA) adalah teknik analisis yang digunakan. Berdasarkan hasil analisis ditemukan bahwa internal locus of control mampu memperkuat pengaruh kompetensi aparatur dan juga sistem pengendalian internal (SPI) pada pencegahan fraud yang dalam hal ini adalah pengelolaan dana desa. Sehingga disarankan agar pemerintahan desa selalu mempertimbangkan kendali diri aparatur desa dalam pengelolaan keuangan desa.

Kata kunci: Fraud, kompetensi, sistem pengendalian internal, internal locus of control
\end{abstract}

\section{ABSTRACT}

The purpose of this study is to examine the influence of village apparatus competencies and internal control systems on prevention of fraud which are moderated by internal locus of control.This research was conducted in all village offices of the City of Denpasar. The number of samples taken was 81 village officials, with a saturated sample method. Data collection is done by questionnaires and interviews. The analysis technique used is the Moderate Regression Analysis (MRA). Based on the results of the analysis it was found that internal locus of control was able to strengthen the influence of apparatus competencies and internal control systems on fraud prevention in managing village funds. So it is recommended that village governments always consider the self-control of village officials in managing village finances.

Keywords: Fraud, competence, internal control system, internal locus of control

\section{PENDAHULUAN}

Adanya perubahan kekuasaan dari pemerintah pusat ke pemerintah daerah diakibatkan oleh desentralisasi politik yang terjadi di Indonesia. Terjadinya desentralisasi memberikan keleluasaan untuk menghasilkan keputusan-keputusan politik tanpa intervensi pemerintah pusat (Dwipayana, 2003). Dengan adanya desentralisasi diharapkan mampu memperbaiki dalam hal pengambilan keputusan yakni dari pengambilan keputusan publik ke tingkat pemerintahan yang paling 
Luh Ayu Marsita Dewi dan I Gusti Ayu Eka Darmayanthi. Pemoderasi ...

rendah. Tingkat pemerintahan yang paling rendah adalah desa (Mardiasmo, 2009:9).

UU No. 6 Tahun 2014 tentang Desa yang ditetapkan Pemerintah pada tanggal 15 Januari 2014 dijelaskan bahwa desa memiliki hak baik itu hak asal usul maupun hak tradisional dalam mengatur kepentingan masyarakat setempat. Pemerintah Indonesia mengeluarkan kebijakan yakni pembentukan Dana Desa sebagai bentuk desentralisasi keuangan menuju desa yang mandiri, serta mampu menjalankan pemerintahannya sendiri. Dalam Peraturan Menteri Desa, Pembangunan Daerah Tertinggal, dan Transmigrasi Republik Indonesia Nomor 21 Tahun 2015 pasal 1 ayat 2 tentang Penetapan Prioritas Penggunaan Dana Desa Tahun 2016 dijelaskan bahwa Dana Desa adalah dana yang bersumber dari Anggaran Pendapatan dan Belanja Negara yang ditransfer melalui Anggaran Pendapatan dan Belanja Daerah kabupaten/kota dan fungsinya untuk mendanai penyelenggaraan pemerintahan, pelaksanaan pembangunan, pembinaan kemasyarakatan, dan pemberdayaan masyarakat.

Dana desa dalam APBN tahun 2018 di seluruh Indonesia berjumlah Rp 60 triliun untuk 82.505 desa. Provinsi Bali pada tahun 2018, dana desa dialokasikan kepada 716 desa untuk 9 kabupaten/kota seperti nampak dalam tabel 1 berikut: 
Tabel 1.

Dana Desa Tahun Anggaran 2018 di Provinsi Bali

\begin{tabular}{llr}
\hline No & Kabupaten & Dana Desa \\
\hline 1 & Kabupaten Badung & $\operatorname{Rp~42.439.183.000~}$ \\
2 & Kabupaten Bangli & $\operatorname{Rp~52.826.236.000~}$ \\
3 & Kabupaten Buleleng & $\operatorname{Rp} 106.882 .607 .000$ \\
4 & Kabupaten Gianyar & $\operatorname{Rp} 51.971 .543 .000$ \\
5 & Kabupaten Jembrana & $\operatorname{Rp~39.664.910.000~}$ \\
6 & Kabupaten Karangasem & $\operatorname{Rp} 64.376 .212 .000$ \\
7 & Kabupaten Klungkung & $\operatorname{Rp} 43.266 .021 .000$ \\
8 & Kabupaten Tabanan & $\operatorname{Rp} 102.310 .276 .000$ \\
9 & Kota Denpasar & $\operatorname{Rp} 27.404 .975 .000$ \\
\hline
\end{tabular}

Sumber: Diektorat Jendral Pajak Kementrian Keuangan, 2018

Adanya perbedaan alokasi dana yang diterima oleh masing-masing desa dikarenakan alokasi dana yang diterima oleh masing-masing desa ditentukan oleh beberapa faktor, yaitu jumlah penduduk, angka kemiskinan, luas wilayah dan tingkat kesulitan goegrafis. Pengelolaan keuangan desa dilaksanakan untuk mewujudkan desa sebagai suatu pemerintahan terdepan sehingga mampu melaksanakan penyelenggaraan pemerintahan dan pembangunan menuju masyarakat adil, makmur, dan sejahtera (Gayatri, 2017). Pengelolaan keuangan desa dilaksanakan dalam masa 1 (satu) tahun anggaran terhitung mulai tanggal 1 Januari sampai dengan 31 Desember (Reasoa, 2015).

Pedoman yang digunakan untuk pengelolaan keuangan desa adalah Peraturan Menteri Dalam Negeri No. 113 Tahun 2014 mengingat didalamnya telah mencakup berbagai prosedur pengelolaan keuangan desa mulai dari perencanaan, pelaksanaan, penatausahaan, pelaporan sampai dengan peranggungjawaban. Namun sampai saat ini masih banyak terjadi kasus penyelewengan dana desa yang dilakukan oleh aparatur desa dan bahkan dengan ikut campurnya pemerintah daerah. Kasus penyimpangan terkait dana desa pernah terjadi di Riau pada tahun 2015. Kasus tersebut melibatkan Kades di Labuhan 
Tangga Kecamatan Bangko, Kabupaten Rohil. Penyimpangan dana desa tersebut merugikan negara sebesar Rp 399 juta dalam anggaran APBD Rohil (detiknews.com). Oleh karena itu, diperlukan suatu cara untuk meminimalisir penyelewangan dari penggunaan dana desa yakni suatu bentuk antisipasi untuk mencegah kasus serupa terjadi.

Komisi Pemberantasan Korupsi (2015) melakukan sebuah kajian yang menunjukkan adanya permasalahan dalam hal sumber daya manusia atas tata kelola keuangan desa. Permasalahan yang dihadapi mulai dari rendahnya kemampuan administrasi yang dimiliki aparat pemerintah desa, yang berakibat pada turunnya profesionalisme kerja. Selain itu, tenaga pendamping desa berpotensi melakukan korupsi/fraud dengan memanfaatkan lemahnya kompetensi aparat desa. Kemudian pada aspek pengawasan permasalahan yang dihadapi yakni inspektorat daerah dalam melakukan pengawasan pengelolaan keuangan di desa masih rendah serta saluran pengaduan masyarakat tidak dikelola dengan baik oleh semua daerah.

Sistem Pengendalian Internal (SPI) sebagai salah satu cara untuk mengarahkan, mengawasi, dan mengukur sumber daya suatu organisasi, serta mempunyai peran penting dalam pencegahan dan pendeteksian penggelapan (fraud) secara dini (Pratama, 2017). Namun, sistem pengendalian internal tidak luput dari kelemahannya, kelemahan ini dapat dimanfaatkan oleh oknum pelaku kecurangan (Martani dan Zaelani, 2011). Jika kelemahan sistem ini didukung oleh internal locus of control maka segala jenis kecurangan dapat dicegah, seperti hasil penelitian dari (Limawan dan Mimba, 2016) menyatakan bahwa locus of control 
ekternal berpengaruh positif terhadap penerimaan perilaku Underreporting of Time (URT). Semakin tinggi locus of control eksternal seorang auditor maka semakin tinggi pula kecenderungan auditor tersebut untuk menerima perilaku URT. Hal ini mengindikasikan bahwa dengan adanya locus of control internal akan mampu mencegah adanya fraud karena locus of control internal sebagai kendali diri seorang individu.

Berkaitan dengan tujuan untuk mengetahui faktor-faktor apa saja yang dapat meningkatkan keefektifan pencegahan fraud, maka penulis tertarik hanya fokus pada variabel pemoderasi yang dapat memberikan pengaruh memperkuat hubungan antara kompetensi aparatur, sistem pengendalian internal dan pencegahan fraud, dengan memilih variabel internal locus of control.

Penelitian ini dilakukan di Kota Denpasar karena Denpasar merupakan kota yang mendapat Dana Desa terkecil dibandingkan dengan Kabupaten lainnya di Provinsi Bali. Kota Denpasar menerima Dana Desa di tahun 2018 sebesar 27.404.975.000, terlampir di lampiran 1. Kota Denpasar sebagai salah satu kota dengan pengelolaan keuangan yang terbukti sangat baik. Hal ini dipertegas oleh hasil Badan Pemeriksa Keuangan (BPK) RI Perwakilan Provinsi Bali yang menunjuk Pemerintah Kota Denpasar sebagai lokasi dalam melakukan pemeriksaan pendahuluan terhadap kinerja dana desa. Dari hasil pemeriksaan tersebut terbukti bahwa desa yang ada di Kota Denpasar memang sangat maju dalam pengelolaan dana desa (Baliberkarya.com).

Berdasarkan uraian latar belakang tersebut, maka rumusan masalah yang menjadi fokus penelitian ini, adalah: 1) Apakah internal locus of control mampu 
memoderasi pengaruh kompetensi aparatur desa pada pencegahan fraud dalam pengelolaan dana desa? 2) Apakah internal locus of control mampu memoderasi pengaruh sistem pengendalian internal (SPI) pada pencegahan fraud dalam pengelolaan dana desa?

Berdasarkan rumusan masalah, maka tujuan yang ingin dicapai dalam penelitian ini, yaitu: 1) untuk mengetahui dan menganalisis internal locus of control memoderasi pengaruh kompetensi aparatur desa pada pencegahan fraud dalam pengelolaan dana desa 2) untuk mengetahui dan menganalisis internal locus of control memoderasi pengaruh sistem pengendalian internal (SPI) pada pencegahan fraud dalam pengelolaan dana desa.

Berdasarkan tujuan penelitian tersebut, penelitian ini diharapkan memberikan manfaat bagi pihak-pihak yang berkepentingan, yaitu: 1) Kegunaan teoritis, hasil penelitian ini diharapkan dapat menambah pengetahuan dan informasi mengenai penerapan teori keagenan yaitu bagaimana agen bertanggungjawab kepada prinsipal atas dana desa agar perilaku kecurangan (fraud) dapat dicegah 2) Kegunaan praktis, hasil penelitian ini sebagai bahan masukan bagi pemangku kepentingan untuk memperbaiki masalah yang ada dalam menciptakan dana desa yang transparan agar program dana desa dapat memberikan manfaat secara optimal kepada masyarakat desa dan menjadi salah satu pilar pembangunan infrastruktur dasar desa.

Teori agensi mengatakan jika agen merupakan pihak yang dikontrak oleh pemegang saham. Karena mereka dipilih, maka pihak manajemen harus mempertanggungjawabkan semua pekerjaan kepada pemegang saham. Sikap 
yakni bagian dari komponen kompetensi menjadi hal penting karena individu yang memiliki sikap akan bertanggungjawab terhadap tugas yang diberikan, maka cenderung untuk tidak melakukan fraud. Oleh karena itu, aparatur desa yang mengurus dana desa sudah seharusnya mempertanggungjawaban dana desa dengan baik.

Individu yang memiliki kompetensi tinggi apabila didukung oleh internal locus of control yang tinggi pula akan mampu mencegah terjadinya fraud. Dimana dalam hal ini, aparatur desa yang sudah berkompeten belum tentu dapat mencegah adanya fraud. Namun, dengan adanya internal locus of control sebagai kendali diri maka aparatur desa tidak akan melakukan fraud sehingga pencegahan fraud lebih optimal. Berdasarkan uraian tentang penelitian terdahulu diatas, maka dapat dirumuskan hipotesis sebagai berikut:

$\mathrm{H}_{1}$ : Internal locus of control mampu memperkuat kompetensi aparatur desa pada pencegahan fraud dalam pengelolaan dana desa.

Penelitian Najahningrum (2013), Pramudita (2013), Zulkarnain (2013), dan Fauwzi (2011) menunjukkan bahwa dengan adanya suatu sistem pengendalian internal yang efektif oleh instansi hal ini dapat menurunkan tingkat kecurangan yang akan dilakukan, sebaliknya jika kualitas sistem pengendalian internal yang buruk, maka hal itu akan menjadi kesempatan bagi karyawan untuk melakukan kecurangan. Oleh karena itu, semakin baik sistem pengendalian internal di dalam suatu instansi maka dapat menurunkan tingkat terjadinya fraud. Namun, sistem pengendalian internal tidak luput dari kelemahannya, kelemahan ini dapat dimanfaatkan oleh oknum pelaku kecurangan (Martani dan Zaelani, 2011). 
Jensen and Meckling menjelaskan bahwa principal dapat memecahkan masalah keagenan dengan cara memberikan kompensasi yang sesuai kepada agen, serta mengeluarkan biaya monitoring, sedangkan untuk hasil monitoring yang maksimal, diperlukan suatu pengendalian internal yang efektif. Seseorang yang memiliki internal locus of control tidak akan merasa bergantung pada orang lain. Dengan hal ini, individu tersebut akan melakukan apapun tanpa tekanan dari orang lain. Sistem pengendalian internal yang lemah, apabila didukung oleh internal locus of control yang tinggi maka fraud dapat dikendalikan. Berdasarkan uraian tentang penelitian terdahulu diatas, maka dapat dirumuskan hipotesis sebagai berikut:

$\mathrm{H}_{2}$ : Internal locus of control mampu memperkuat sistem pengendalian internal pada pencegahan fraud dalam pengelolaan dana desa.

\section{METODE PENELITIAN}

Pendekatan yang digunakan dalam penelitian ini adalah pendekatan kuantitatif yang berbentuk asosiatif. Penelitian ini mengambil lokasi di desa yang berada di wilayah Pemerintahan Kota Denpasar. Kota Denpasar dipilih sebagai lokasi penelitian karena pada tahun 2018 Kota Denpasar sebagai salah satu kota dengan pengelolaan keuangan yang terbukti sangat baik. Hal ini dipertegas oleh hasil Badan Pemeriksa Keuangan (BPK) RI Perwakilan Provinsi Bali yang menunjuk Pemerintah Kota Denpasar sebagai lokasi dalam survey terhadap kinerja dana desa. Desain penelitian disajikan pada Gambar 1. Berikut: 


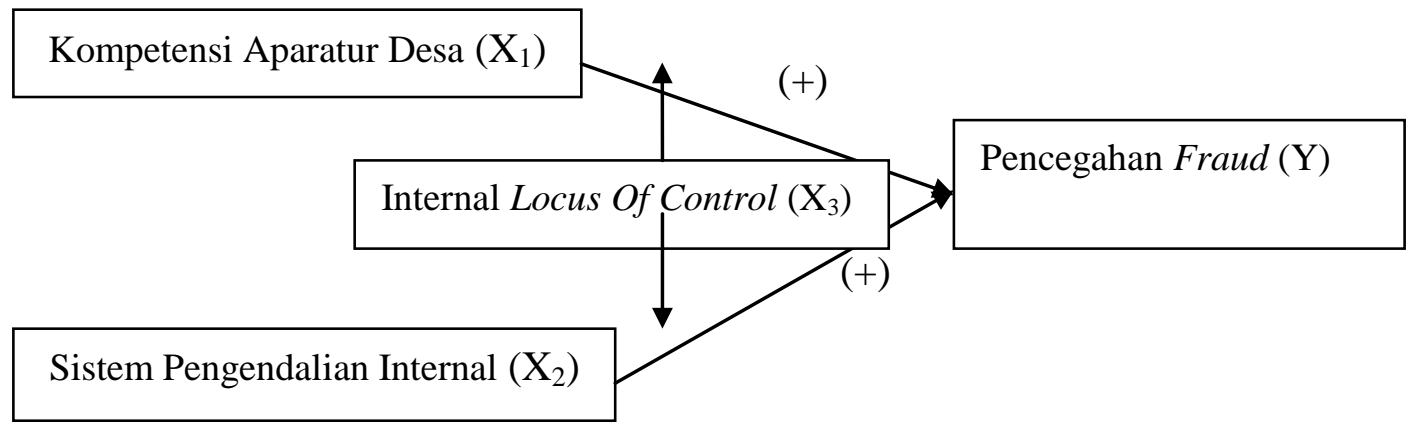

Sumber: Data diolah, 2018

\section{Gambar 1. Kerangka Konseptual}

Perangkat desa yang langsung terlibat dalam pengelolaan keuangan dan yang bertanggungjawab dalam penyusunan laporan keuangan merupakan subjek penelitian. Sedangkan yang menjadi obyek penelitian adalah pencegahan fraud pengelolaan dana desa yang ada di Kota Denpasar. Variabel terikat dalam penelitian ini adalah pencegahan fraud $(\mathrm{Y})$. Variabel bebas dalam penelitian ini adalah kompetensi aparatur desa $\left(\mathrm{X}_{1}\right)$, sistem pengendalian internal $\left(\mathrm{X}_{2}\right)$.Variabel moderasi dalam penelitian ini adalah internal locus of control $\left(\mathrm{X}_{3}\right)$.

Jenis data digunakan dalam penelitian ini adalah sebagai berikut: 1) data kuantitatif berupa data jumlah responden yang menjawab kuesioner yang diukur menggunakan skala likert 5 point dan rincian dana desa. 2) Data kualitatif berupa adalah daftar nama-nama desa yang menerima dana desa. Sumber data yang dipergunakan dalam penelitian ini adalah data primer, berupa informasi yang dikumpulkan berdasarkan jawaban responden pada kuesioner.

Perangkat desa yang terlibat dalam pengelolaan dana desa yaitu mulai dari Kepala Desa, Sekretaris Desa, dan Kepala Urusan Keuangan merupakan populasi dari penelitian ini, dimana jumlah populasi penelitian ini sebanyak 81 responden yang terdiri dari 27 desa dari Kota Denpasar. Sampel dalam penelitian ini 
menggunakan teknik sensus hal ini dikarenakan jumlah populasinya tidak lebih besar 100 orang responden, maka populasi yang diambil adalah keseluruhan populasi yang ada pada Kota Denpasar yaitu 81 responden.

Kompetensi aparatur diukur dengan enam indikator, yaitu latar belakang \& tingkat pendidikan, prinsip-prinsip corporate governance, sikap \& perilaku aparatur, peran kemasyarakatan aparatur, penguasaan pengetahuan dan keahlian, kemampuan berkarya. Sistem pengendalian internal diukur menggunakan lima indikator yaitu, lingkungan pengendalian, penaksiran risiko, aktivitas pengendalian, informasi dan komunikasi, pemantauan.

Metode pengumpulan data yang digunakan dengan teknik pengumpulan kuesioner. Kuisioner yang digunakan merupakan kusioner pada penelitian Pratama (2017) untuk variabel pencegahan fraud, Aruan (2003) untuk variabel kompetensi aparatur desa, Fikri, dkk., (2015) untuk variabel sistem pengendalian internal, Novita (2011) untuk variabel internal locus of control.

Teknik analisis data penelitian ini yaitu Moderate Regression Analysis (MRA). Adapun model persamannya adalah:

$Y=\alpha+\beta_{1} X_{1}+\beta_{2} X_{2}+\beta_{3} X_{3+} \beta_{4} X_{1} * X_{3}+\beta_{5} X_{2} * X_{3}+\varepsilon$

Keterangan:

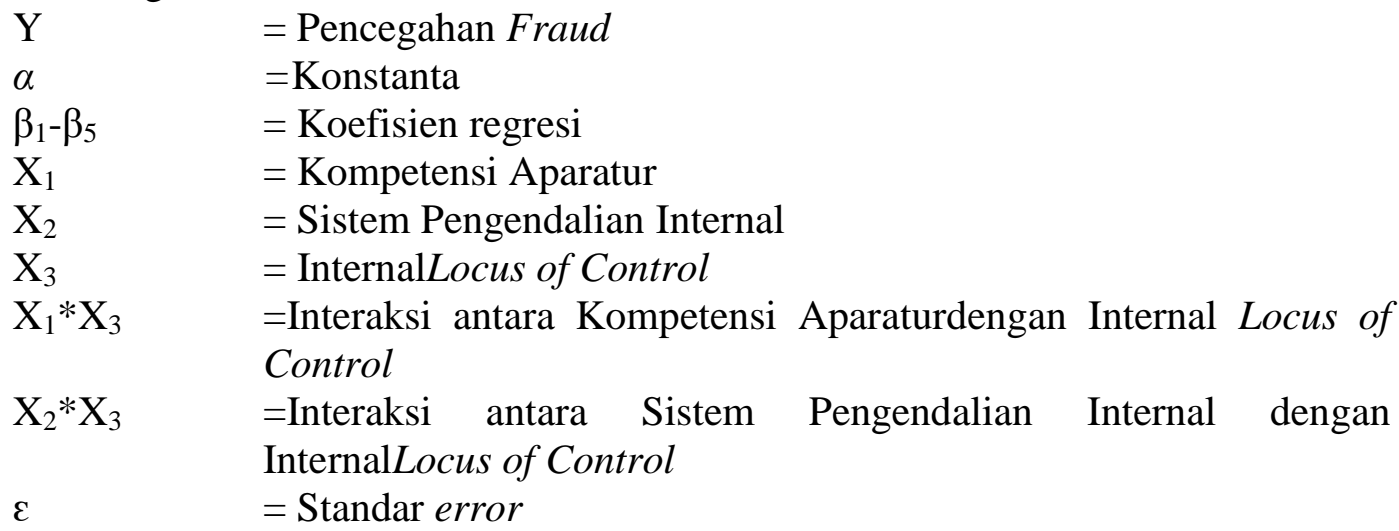


Uji validitas digunakan sebagai uji kualitas data yakni untuk menguji apakah pernyataan dalam kusioner valid atau tidak. Sedangkan, uji reliabilitas dilakukan untuk mengetahui seberapa besar variabel dapat dipercaya. Uji normalitas dan uji heteroskedastisitas dugunakan sebagai uji asumsi klasik dalam penelitian ini.

Koefisien regresi yang disesuaikan (adjused $R$ square) digunakan sebagai analisis. Sedangkan untuk menguji pengaruh variabel independen terhadap variabel dependen layak digunakan dilakukan uji F. Uji t digunakan sebagai uji hipotesis yang menjelaskan sebarapa jauh pengaruh variabel independen untuk menerangkan variasi variabel dependen.

\section{HASIL DAN PEMBAHASAN}

Hasil dari penyebaran 81 kuisioner yakni semua eksemplar kuisioner kembali serta pengisian yang lengkap dan memenuhi kriteria, hal ini mengindikasikan bahwa tidak ada kuisioner yang gugur, sehingga menghasilkan response rate 100 persen dengan useable response rate sebesar 100 persen. Berdasarkan profil dari 81 responden yang mengisi kuisioner, maka didapatkan karakteristik responden penelitian diantaranya gender, umur, jabatan/bagian, latar belakang pendidikan, dan lama menjabat.

Karaketeristik responden penelitian ini yaitu perangkat desa yang mengelola dana desa terbanyak adalah laki-laki yakni 54 responden dibandingkan perempuan. Kelompok usia yang dominan yaitu kelompok usia 36-50 tahun sebanyak 40 responden. Latar belakang pendidikan terbanyak yakni berasal dari 
ilmu sosial sebanyak 39 responden. Selain itu, responden paling banyak menduduki jabatan selama 1-5 tahun, dengan jumlah 35 responden.

Berikut diuraikan mengenai proses pengolahan data menguji hipotesis pertama dan hipotesis kedua, yang telah dijabarkan pada bagian sebelumnya serta memberikan uraian mengenai hasil pengolahan data. Sebelumnya dilakukan uji statistik deskriptif, uji asumsi klasik sebelum kemudian uji Moderate Regression Analysis (MRA) dengan pengujian koefisien determinasi $\left(\mathrm{R}^{2}\right)$, menilai kelayakan model regresi (uji F) untuk pengujian kedua hipotesis yang ada dalam penelitian.

Tabel 1.

Hasil Statistik Deskriptif

\begin{tabular}{lccccc}
\hline \multicolumn{1}{c}{ Variabel } & N & Min. & Max. & Mean & $\begin{array}{c}\text { Std. } \\
\text { Deviasi }\end{array}$ \\
\hline Kompetensi Aparatur & 81 & 57 & 95 & 79,65 & 6,516 \\
Sistem Pengendalian Internal & 81 & 53 & 85 & 71,90 & 6,186 \\
Internal Locus of Control & 81 & 24 & 40 & 33,78 & 4,591 \\
Pencegahan Fraud & 81 & 34 & 50 & 41,99 & 3,378 \\
\hline Sumber: Data diolah, 2018 & & & & &
\end{tabular}

Tabel 1 menyajikan hasil mengenai analisis deskriptif dalam penelitian ini. Berdasarkan data yang disajikan dalam tabel 1 dapat diketahui bahwa jumlah pengamatan yakni 81 responden. Pengamatan sebanyak 81 responden ini karena penelitian dilakukan pada 3 orang responden dalam 1 kantor desa di Kota Denpasar yang berjumlah 27 desa. Nilai minimum dan maksimum untuk variabel kompetensi aparatur $\left(\mathrm{X}_{1}\right)$ adalah sebesar 57 dan 95 dengan nilai rata-rata sebesar 79,65. Standar deviasi pada variabel kompetensi aparatur adalah sebesar 6.516. Hal ini menunjukkan bahwa standar penyimpangan data terhadap nilai rataratanya adalah 6.516 . 
Untuk nilai minimum dan maksimum variabel sistem pengendalian internal adalah sebesar 53 dan 85. Nilai rata-rata pada variabel sistem pengendalian internal sebesar 79,65, dan apabila dibagi dengan 19 item pertanyaan akan menghasilkan nilai sebesar 4,192. Dengan ini berarti responden yang menjawab kuisioner untuk variabel sistem pengendalian internal rata-rata adalah 4. Standar deviasi pada variabel kompetensi aparatur adalah sebesar 6.516.

Variabel internal locus of control $\left(\mathrm{X}_{3}\right)$ memiliki nilai minimum sebesar 24 dan nilai maksimum sebesar 40 dengan nilai rata-rata sebesar 33,78. Untuk nilai standar deviasi pada variabel internal locus of control adalah sebesar 4,951. Dengan ini menunjukkan standar penyimpangan data terhadap nilai rata-ratanya adalah 4,951 .

Hasil statistik deskriptif untuk nilai minimum dan maksimum variabel pencehagan fraud (Y) sebesar 34 dan 50 dengan nilai rata-rata sebesar 41,99 apabila dibagi dengan 10 item pertanyaan akan menghasilkan nilai 4,199 yang artinya rata-rata responden memberikan penilaian pada skor 4 untuk item pertanyaan pencegahan fraud. Nilai standar deviasi pada variabel senjangan anggaran adalah sebesar 3,378.

Hasil uji validitas menunjukkan bahwa instrumen penelitian yang terdiri item-item pertanyaan Kompetensi Aparatur $\left(\mathrm{X}_{1}\right)$, Sistem Pengendalian Internal $\left(\mathrm{X}_{2}\right)$, Internal Locus of Control $\left(\mathrm{X}_{3}\right)$ dan Pencegahan Fraud (Y) adalah valid dikarenakan nilai pearson correlation lebih besar dari 0,30. Sedangkan hasil uji reliabilitas menunjukkan bahwa nilai Conbrach's Alpha masing-masing variabel lebih besar dari 0,60 yang artinya instrumen penelitian adalah reliable. 
Tabel 2.

Hasil Uji Normalitas

\begin{tabular}{ll}
\hline Kolmogorov-smirnov & Unstandardized Residual \\
\hline $\mathrm{N}$ & 81 \\
Asymp- sig (2-tailed) & 0,741 \\
\hline
\end{tabular}

Sumber: Data diolah, 2018

Tabel 2 menyajikan data terkait dengan hasil uji normalitas, dari tabel tersebut dapat diketahui bahwa nilai dari Asymp. Sig (2-tailed) adalah 0,741 yakni lebih besar dari 0,05 . Hal ini menunjukkan distribusi data dalam penelitian telah normal.

Tabel 3.

Hasil Uji Heteroskedastisitas

\begin{tabular}{|c|c|c|c|c|}
\hline \multirow[t]{2}{*}{ Model } & \multicolumn{2}{|c|}{ Unstandarized Coefficient } & \multirow{2}{*}{$\begin{array}{r}\begin{array}{l}\text { Standardized } \\
\text { Coefficient }\end{array} \\
\text { Beta }\end{array}$} & \multirow[t]{2}{*}{ Sig } \\
\hline & $\mathrm{B}$ & Std. Error & & \\
\hline (Constant) & 0,763 & 2,682 & & 0,777 \\
\hline Kompetensi Aparatur & 0,065 & 0,032 & 0,277 & 0,094 \\
\hline $\begin{array}{l}\text { Sistem Pengendalian } \\
\text { Internal }\end{array}$ & 0,006 & 0,038 & 0,023 & 0,879 \\
\hline Internal Locus of Control & $-0,033$ & 0,050 & $-0,098$ & 0,514 \\
\hline $\mathrm{X} 1 . \mathrm{X} 3$ & $-0,001$ & 0,001 & $-0,213$ & 0,080 \\
\hline X2.X3 & 0,000 & 0,001 & $-0,058$ & 0,661 \\
\hline
\end{tabular}

Selain uji normalitas dilakukan uji heteroskedastisitas dengan uji glejser, yakni meregresi nilai absolute residual dari model yang diestimasi terhadap variabel bebas. Hasil uji heteroskedastisitas menunjukkan nilai signifikansi semua diatas 5 persen yang mengindikasikan tidak terdapat heteroskedastisitas. 
ISSN: 2302-8556

E-Jurnal Akuntansi Universitas Udayana

Vol.26.3.Maret (2019): 2375 -2395

Tabel 4.

Hasil Analisis Regresi Moderasi

\begin{tabular}{|c|c|c|c|c|c|c|c|}
\hline \multirow{2}{*}{\multicolumn{2}{|c|}{ Variabel }} & \multicolumn{2}{|c|}{$\begin{array}{c}\text { Unstandarized } \\
\text { Coefficient }\end{array}$} & \multirow{2}{*}{$\begin{array}{c}\begin{array}{c}\text { Standarized } \\
\text { Coefficient }\end{array} \\
\text { Beta }\end{array}$} & \multirow[t]{2}{*}{$\mathbf{t}$} & \multirow[t]{2}{*}{ Sig. } & \multirow[t]{2}{*}{$\begin{array}{l}\text { Hasil Uji } \\
\text { Hipotesis }\end{array}$} \\
\hline & & $\mathbf{B}$ & $\begin{array}{c}\text { Std. } \\
\text { Error }\end{array}$ & & & & \\
\hline \multicolumn{2}{|c|}{ (Constant) } & 11,140 & 4,308 & & 2,586 & 0,012 & \\
\hline \multicolumn{2}{|c|}{ Kompetensi Aparatur } & 0,146 & 0,051 & 0,282 & 2,857 & 0,006 & \\
\hline \multicolumn{2}{|c|}{ Sistem Pengendalian } & \multicolumn{5}{|c|}{ Internal } & \\
\hline \multicolumn{2}{|l|}{$\begin{array}{l}\text { Internal Locus of } \\
\text { Control }\end{array}$} & 0,185 & 0,081 & 0,251 & 2,291 & 0,025 & \\
\hline \multicolumn{2}{|l|}{$\mathrm{X} 1 . \mathrm{X} 3$} & 0,002 & 0,001 & 0,216 & 2,463 & 0,016 & $\mathrm{H}_{1}$ Diterima \\
\hline \multicolumn{2}{|l|}{$\mathrm{X} 2 . \mathrm{X} 3$} & 0,002 & 0,001 & 0,226 & 2,348 & 0,022 & $\mathrm{H}_{2}$ Diterima \\
\hline Adjusted $\mathrm{R}_{\text {square }}$ & 0,478 & & & & & & \\
\hline $\mathrm{F}_{\text {hitung }}$ & 15,656 & & & & & & \\
\hline Sig. $F_{\text {hitung }}$ & 0,000 & & & & & & \\
\hline
\end{tabular}

Berdasarkan tabel 4. nilai Adjusted R-Square adalah sebesar 0,478. Hal ini menunjukkan 47,8 persen perubahan yang terjadi pada variabel pencegahan fraud dapat dijelaskan oleh variabel kompetensi aparatur dan sistem pengendalian internal serta dimoderasi oleh variabel intenal locus of control, sedangkan sisanya sebesar 48,9 persen dijelaskan oleh variabel lain yang tidak terdapat dalam penelitian ini.

Berdasarkan data yang disajikan dalam tabel 4 dapat diketahui nilai $\mathrm{F}$ hitung adalah 15,656 dengan tingkat signifikansi 0,000 yakni kurang dari 0,05. Hal tersebut menunjukkan bahwa variabel kompetensi aparatur dan sistem pengendalian internal secara simultan berpengaruh pada pencegahan fraud. Hasil uji F menunjukkan model regresi berganda layak digunakan sebagai alat analisis.

Uji $\mathrm{t}$ dalam penelitian ini dilakukan dengan membandingkan hasil pengujian dengan tingkat signifikansi menggunakan taraf nyata $(\alpha)$ sebesar 0,05 . Pengaruh interaksi antara variabel kompetensi dengan internal locus of control $\left(\mathrm{X}_{1} \mathrm{X}_{3}\right)$ terhadap pencegahan fraud $(\mathrm{Y})$ menunjukkan tigkat signifikansi sebesar 0, 016 lebih kecil dari $\alpha=0,05$, maka terjadi interaksi antara kompetensi aparatur 
Luh Ayu Marsita Dewi dan I Gusti Ayu Eka Darmayanthi. Pemoderasi ...

dengan internal locus of control. Pengaruh variabel interaksi antara variabel sistem pengendalian internal dengan internal locus of control $\left(\mathrm{X}_{2} \mathrm{X}_{3}\right)$ terhadap pencegahan fraud (Y) menunjukkan tingkat signifikansi sebesar 0,022 lebih kecil dari $\alpha=0,05$, maka terjadi interaksi antara sistem pengendalian internal dengan internal locus of control.

Berdasarkan hasil pengolahan data analisis Moderate Regression Analysis (MRA), maka persamaan regresi, yaitu:

$$
\mathrm{Y}=11,140+0,146 \mathrm{X}_{1}+0,018 \mathrm{X}_{2}+0,185 \mathrm{X}_{3}+0,002 \mathrm{X}_{1} \cdot \mathrm{X}_{3}+0,002 \mathrm{X}_{2} \cdot \mathrm{X}_{3}+\varepsilon
$$

Pengaruh variabel kompetensi aparatur $\left(\mathrm{X}_{1}\right)$ dengan pencegahan fraud $(\mathrm{Y})$ menunjukkan tingkat signifikansi sebesar 0,006 lebih kecil dari $\alpha=0,05$, maka hal ini menunjukkan bahwa kompetensi berpengaruh positif pada pencegahan fraud.

Pengaruh variabel sistem pengendalian internal $\left(\mathrm{X}_{2}\right)$ dengan pencegahan fraud (Y) menunjukkan tingkat signifikansi sebesar 0,768 lebih besar dari $\alpha=0,05$, maka hal ini menunjukkan bahwa sistem pengendalian internal tidak berpengaruh pada pencegahan fraud. Hal ini dikarenakan responden yang menjawab kuisioner bukanlah pihak yang melakukan pengawasan seperti BPKP mengingat monev dilakukan hanya setiap 6 bulan sekali. Sehingga dalam hal ini kuisioner yang diberikan bukan kepada orang yang betul-betul melakukan pengawasan terhadap dana desa tetapi hanya kepada perangkat desa yang mengelola dana desa.

Berdasarkan hasil perhitungan dengan menggunakan uji Moderated Regression Analysis (MRA) yang ditunjukkan pada Tabel 4. apabila dilihat dari tingkat signifikansinya yakni $0,016<0,05$ menyatakan bahwa internal locus of control berpengaruh positif terhadap hubungan kompetensi aparatur desa pada 
pencegahan fraud dapat diterima. Hal ini selaras dengan penelitian dari (Fiqih, 2016), (Widyatama dan Novita, 2017), (Pramita, 2014) yang menyatakan bahwa kompetensi aparatur desa dan internal locus of control mampu mencegah adanya fraud. Hal ini membuktikan bahwa pada umumnya aparatur memiliki internal locus of control belum sepenuhnya bagus. Untuk berperilaku jujur dan mematuhi peraturan-peraturan belum sepenuhnya diterapkan dalam pemerintah desa. Bawahan lebih takut terhadap pimpinanya dari pada patuh pada Peraturan Pemerintah (PP) sekalipun pimpinannya berperilaku salah atau tidak jujur. Sehingga dalam hal ini, dapat disimpulkan bahwa internal locus of control dari aparatur pemerintah desa mendukung segala kompetensi yang dimiliki oleh aparatur desa itu sendiri untuk mencegah terjadinya fraud dalam pengelolaan dana desa.

Hipotesis kedua yang menyatakan bahwa internal locus of control mampu memperkuat hubungan sistem pengendalian internal pada pencegahan fraud berhasil diterima. Begitu halnya apabila dilihat dati tigkat signifikansinya 0,022<0,05. Hasil penelitian ini konsisten dengan pernyataan oleh (Hermiyeti, 2008), (Purwitasari, 2013), dan (Aranta, 2013) yang pada intinya menyatakan bahwa internal locus of control yang baik, sistem pengendalian internal yang handal dapat mencegah terjadinya fraud dalam pengelolaan dana desa.

Salah satu faktor penyebab terjadinya kecurangan yaitu dalam organisasi tersebut terdapat perilaku pimpinan ataupun staf yang tidak sesuai dengan pedomannya. Sehingga dalam hal ini dapat disimpulkan bahwa internal locus of control yang tinggi dari aparatur pemerintah desa mendukung implementasi 
sistem pengendalian internal untuk mencegah terjadinya fraud dalam pengelolaan dana desa, terlebih bahwa dana desa diawasi oleh pemerintah pusat, provinsi, kabupaten/kota dan lembaga pengawas keuangan independen.

\section{SIMPULAN}

Berdasarkan hasil dan pembahasan analisis data yang telah dijabarkan pada bagian sebelumnya, maka simpulan penelitian yaitu internal locus of control mampu memperkuat hubungan kompetensi aparatur desa dan sistem pengendalian internal pada pencegahan fraud.

Berdasarkan hasil penelitian dan simpulan, maka saran-saran yang dapat diberikan penulis adalah sebagai berikut. Penelitian ini hanya menggunakan 2 variabel saja, untuk peneliti selanjutnya diharapkan dapat menambah variabelvariabel lainnya, baik variabel bebas maupun variabel moderasi seperti budaya organisasi, pedoman atau standar akuntansi, sistem informasi akuntansi yang mempengaruhi pencegahan fraud, serta variabel lain dari segi keperilakuan dan manjerial seperti total quality management, moralitas, dan sebagainya. Saran untuk pemerintahan desa agar selalu mempertimbangkan kendali diri atau internal locus of control aparatur desa sebagai faktor yang perlu dipertimbangkan dalam pengelolaan keuangan yakni dalam merumuskan anggaran keuangan serta pertanggung jawaban. .

\section{REFERENSI}

Ananta, Kurniawan. (2017). Pencegahan Fraud Dalam Pengelolaan Keuangan Desa. Jurnal Ilmiah Akuntansi Dan Bisnis.

Aranta, Petra Zulia. (2013). Pengaruh Moralitas Aparat Dan Asimetri Informasi 
Terhadap Kecenderungan Kecurangan Akuntansi (Studi Empiris Pemerintah Kota Sawahlunto). Tesis. Fakultas Ekonomi Universitas Negeri Padang.

Aruan, N. (2003). Kompetensi Aparatur Pemerintah Daerah Studi Empiris Di Jawa Timur. Penerbit Badan Penelitian Dan Pengembangan Propinsi Jawa Timur.

Atmadja, A. T., \& Saputra, A. K. (2017). Pencegahan fraud dalam pengelolaan keuangan desa. Jurnal Ilmiah Akuntansi Dan Bisnis, 12(1), 7-16.

Barth, M., Landsman, W. dan Lang, M. 2008. International Accounting Standards and Accounting Quality.Journal of Accounting Research, 46(3), 467-498.

Cai, L., Asheq, R. dan Courtenay, S. 2008. The Effect of IFRS and its Enforcement on Earnings Management: An International Comparison. Social Science Research Network Electronic Paper Collection, (Online), (http://ssrn.com/abstract=1473571, diakses 26 Desember 2015).

Ewert, R. dan Wagenhofer, A. 2005. Economic Effects of Tightening Accounting Standards to Restrict Earnings Management.The Accounting Review.Vol. 80, No.4 2005. Pp. 1101-1124.

Fikri, Ali., Biana Adha Inapty dan Rr. Sri Pancawati Martiningsih. (2015). Pengaruh Penerapan Standar Akuntansi Pemerintahan, Kompetensi Aparatur Dan Peran Audit Internal Terhadap Kualitas Informasi Laporan Keuangan Dengan Sistem Pengendalian Intern Sebagai Variabel Moderating (Studi Empiris Pada SKPD-SKPD Di Pemprov. NTB). Simposium Nasional Akuntansi XVIII, Medan.

Gayatri, Sari Widhiyani, dan Yenni Latrini (2009). Pengelolaan, Akuntabilitas, and Keuangan Dana. "Jurnal Akuntansi dan Bisnis Universitas Udayana: $175-82$.

Ghozali, (2016). “Aplikasi Analisis Multivariete Dengan Program IBM SPSS 23.” In IBM SPSS 23, , 52.

Hermiyatti. (2011). Pengaruh Penerapan Pengendalian Internal Terhadap Fraud Pengadaan. Journal.uii.ac.id.

Lakonishok, J., Andrei Shleifer, and R.W. Vishny. 1994. Contrarian Investment, Extrapolation and Risk. The Journal of Finance. Vol. 49 Issue 5 Pp. 15411578

Limawan, Yenni Fransisca, dan Ni Putu Sri Harta Mimba. (2016). "Pengaruh Komitmen Organisasi , Locus Of Control Dan Tekanan Anggaran Waktu Audit Pada Penerimaan Underreporting Of Time Fakultas Ekonomi Dan 
Bisnis Universitas Udayana ( Unud ), Bali , Indonesia Tujuan Audit Atas Lap.” E-Jurnal Akuntansi Universitas Udayana 15: 799-831.

Litzenberger, Robert H. and Krishna Ramaswamy. 1979. The Effect of Personal Taxes and Divident on Capital asset prices: Theory and Emperical evidence. Journal of Financial Economic 7. No 2 Pp: 163-195

Mardiasmo. (2009). Akuntansi Sektor Publik. Yogyakarta: Andi.

Monfardini, Patrizio. (2010). Accountability In The New Publicsector: A Comparative Case Study. International Journal of Public Sector Management, 23 (7), pp:632-646.

Morse, Dale. 1981. Price and Trading Volume Reaction Surrounding Earnings Announcements : A Closer Examination. Journal of Accounting Research, 19 (Autumn 1981) Pp 374-383

Mulgan, Richard. (2008). Public Sector Reform In New Zealand: Issues Of Public Accountability. Australian National University, Australia.

Mzenzi, Siasa Issa. (2012). External Auditing And Accountability In The Tanzanian Local Government Authorities. Managerial Auditing Journal, 30 (6/7), pp:681702.

Peraturan Menteri Dalam Negeri Republik Indonesia Nomor 113 Tahun 2014 Tentang Pengelolaan Keuangan Desa.

Petunjuk Pelaksanaan Bimbingan Konsultasi Pengelolaan Keuangan Desa Deputi Bidang Pengawasan Penyelenggaraan Keuangan Daerah Badan Pengawasan Keuangan dan Pembangunan Tahun 2015.

Pratama, Andika. (2017)."Pengaruh Kompetensi Sumber Daya Manusia, Penerapan Sistem Akuntansi Keuangan Daerah, Dan Peran Audit Internal Terhadap Kualitas Laporan Keuangan Pemerintah Daerah Dengan Variabel Moderasi Sistem Pengendalian Internal Pemerintah." Skripsi.

Prawira, I Made Darma., Herawati, Nyoman Trisna., Surya, Nyoman Ari. (2014). Pengaruh Moralitas Individu, Asimetri Informasi Dan Efektivitas Pengendalian Internal Terhadap Kecenderungan Kecurangan (Fraud) Akuntansi. Universitas Pendidikan Ganesha, Vol. 2, No. 1.

Pramita. (2011).Subyektif, Norma-norma, Kendali Perilaku, dan Intensi, and Manajer Dalam.“Jurnal Akuntansi Dan Keuangan Indonesia Pengaruh Locus Of Control Terhadap Hubungan Sikap." 8(2): 123-40.

Rahman, M. A., Suwandi, M., \& Hamid, A. (2016). Transparansi dan 
akuntabilitas pengelolaan keuangan alokasi dana desa (ADD) dalam pencapaian good governance (Studi Empiris di Kecamatan Bontomarannu Kabupaten Gowa). Jurnal Manajemen Ide Dan Inspirasi, 3(2).

Reasoa, Imelda. (2015). Pengelolaan Keuangan Desa. E-Jurnal Akuntansi dan Bisnis.

Riyanto, Teguh. (2015). Akuntabilitas Finansial Dalam Pengelolaan Alokasi Dana Desa (Add) Di Kantor Desa Perangat Selatan Kecamatan Marangkayu Kabupaten Kutai Kartanegara. E-Jurnal, 3 (1), h: 119-130.

Sartika D.K., W. Cipta., dan I W. Bagia. (2014). Pengaruh Sistem Pengendalian Intern Pemerintah dan Pengawasan Keuangan Daerah Terhadap Nilai Informasi Laporan

Seputro, H. Y., Wahyuningsih, S. D., \& Sunrowiyati, S. (2017). Potensi fraud dan strategi anti fraud pengelolaan keuangan desa. Jurnal Penelitian Teori Dan Terapan Akuntansi, 2(1), 79-93.

Stice, Earl K. 1991. The Market Reaction to 10-K and 10-Q Filings and to Subsequent The Wall Street Journal Earning Announcement. The Accounting Review. January 1991 Pp 42-55.

Sugiyono. 2014. Bandung: Alfabeta Metode Penelitian Kuantitatif, Kualitatif Dan $R \& D$.

Tuanakotta, Theodorus M. (2012). Akuntansi Forensik Dan Audit Investigatif. Penerbit: Salemba Empat.

Ugoh, Samuel, Wilfred Ukpere. (2009). Problems And Prospects Of Budgeting And Budget Implementation In Local Government System In Nigeria. African Journal Of Business Management, 3 (12), Pp:836-846.

Widyatama, Arif, and Lola Novita. (2017). "Pengaruh Kompetensi Dan Sistem Pengendalian Internal Terhadap Akuntabilitas Pemerintah Desa Dalam Mengelola Alokasi Dana Desa ( ADD ).” 2(2): 1-20.

Yulianah, Y. (2015). Potensi penyelewengan alokasi dana desa dikaji menurut Peraturan Menteri Dalam Negeri nomor 37 tahun 2007 tentang pengelolaan keuangan desa. Jurnal Hukum Mimbar Justitia, 1(2), 608-627.

Zirman, Edvan, dan Rozi. (2010). Pengaruh Kompetensi Aparatur Pemerintah Daerah, Penerapan Akuntabilitas Keuangan, Motivasi Kerja dan Ketaatan Pada Peraturan Perundangan terhadap Akuntabilitas Kinerja Instansi Pemerintah. Jurnal Ekonomi 18 